\title{
A PRODUÇÃO DO ESPAÇO E MORFOLOGIA URBANA EM PRESIDENTE PRUDENTE-SP
}

\author{
Claudinei da Silva Pereira \\ Universidade Estadual Paulista - Unesp \\ claudinei.kau@gmail.com
}

\begin{abstract}
RESUMO
A cidade de Presidente Prudente teve origem no contexto da expansão do cultivo do café, quando a terra já era mercadoria. A propriedade privada da terra é central neste trabalho para a compreensão de processos contemporâneos de produção do espaço urbano. $O$ artigo analisa a expansão territorial recente e seus desdobramentos sobre a morfologia urbana, resultando em distintas tipologias de loteamentos residenciais, formação de vazios urbanos e na permanência dos lotes não edificados, vinculados a práticas especulativas sobre a terra. A propriedade privada da terra rural e urbana são basilares para a compreensão dos agentes produtores do espaço urbano e dos seus vetores de expansão. Adotou-se como procedimentos metodológicos a pesquisa bibliográfica, levantamento de dados sobre as terras pertencentes a empresas de incorporação imobiliária, mapeamento e caracterização de loteamentos com fins residenciais, vazios urbanos e lotes não edificados nos anos de 2010 e 2018. O tecido urbano expandiu de forma rápida e descontínua nas últimas décadas, motivado por interesses fundiários/imobiliários e conivência do poder público local ao beneficiar o capital incorporador e os proprietários fundiários através de medidas como a ampliação do perímetro urbano e das escolhas locacionais para a construção dos grandes conjuntos habitacionais populares.
\end{abstract}

Palavras-chave: Vazios urbanos. Loteamentos. Mercado fundiário. Cidade média.

\section{LA PRODUCCIÓN DEL ESPACIO Y MORFOLOGÍA URBANA EN PRESIDENTE PRUDENTE-SP}

\begin{abstract}
RESUMEN
La ciudad de Presidente Prudente tuvo origen en el contexto de expansión del cultivo del café, cuando la tierra ya era una mercancía. La propiedad privada de la tierra es fundamental en este trabajo para comprender los procesos contemporáneos de producción del espacio urbano. El artículo analiza la reciente expansión territorial y sus ramificaciones en la morfología urbana, que resultó en diferentes tipos de urbanizaciones residenciales, la formación de vacíos urbanos y la permanencia de lotes no construidos, vinculados a prácticas especulativas en la tierra. La propiedad privada de las tierras rurales y urbanas es importante para la comprensión de los agentes productores del espacio urbano y sus vectores de expansión. Se adoptaron procedimientos metodológicos como la investigación bibliográfica, el levantamiento de datos sobre tierras pertenecientes a empresas de desarrollo inmobiliario, la cartografía y la caracterización de urbanizaciones para fines residenciales, los vacíos urbanos y los lotes no construidos en 2010 y 2018. El tejido urbano se ha expandido rápida y discontinuamente en los últimos decenios, motivado por los intereses inmobiliarios y la connivencia del poder público local en beneficio del capital promotor y los propietarios de tierras mediante medidas como la ampliación del perímetro urbano y las opciones de ubicación para la construcción de grandes conjuntos de viviendas populares.
\end{abstract}

Palabras-clave: Vacío urbano. Urbanizaciones. Mercado de tierras. Ciudad intermedia.

\section{INTRODUÇÃO}

O artigo aborda uma cidade média situada na rede urbana paulista, considerando a terra como eixo central de análise dos processos de ampliação do tecido urbano. A gênese da cidade de Presidente Prudente ocorreu na segunda década do século $X X$, quando a terra tinha se metamorfoseado em mercadoria no contexto de expansão da atividade cafeeira no estado de São Paulo (ABREU, 1972; SPOSITO, 1990). De tal modo, a dinâmica de apropriação de terras como mercadoria vincula-se desde sua origem.

$\begin{array}{lllll}\text { Caminhos de Geografia } & \text { Uberlândia-MG } & \text { v. 22, n. } 83 & \text { out./2021 } & \text { p. 200-218 Página } 200\end{array}$


Este artigo tem por objetivo analisar a expansão territorial recente e seus desdobramentos sobre a morfologia urbana, resultando em distintas tipologias de loteamentos residenciais, formação de vazios urbanos e na permanência dos lotes não edificados, vinculados a práticas especulativas sobre a terra.

Caracterizamos as áreas urbanas e em urbanização a partir dos processos de expansão territorial recente, com recorte temporal nos anos de 2010 e 2018. Para isso, baseamo-nos em elementos da morfologia urbana (CAPEL, 2013) que são: o plano, os usos do solo e o estudo morfológico integrado de áreas da cidade. $O$ trabalho dialoga com outras pesquisas que tratam da produção do espaço urbano (NASCIMENTO, 2014; BARCELLA e MELAZZO, 2020), conjuntos habitacionais de interesse social (OLIVEIRA, 2015; SANTOS, 2020) e loteamentos fechados para população de renda média-alta (SPOSITO e GÓES, 2013), vinculados aos seus conteúdos socioespaciais.

A apropriação privada do solo urbano conforma lógicas fundiárias relacionadas à acumulação de terras como reserva patrimonial (SAYAD, 1977) ou ativo (ABRAMO, 1989). Processos que ocasionam a ampliação e descontinuidades no tecido urbano em Presidente Prudente, e justificam o estudo dos agentes responsáveis por tal dinâmica e o mapeamento das morfologias produzidas.

Para cumprir o objetivo proposto, o texto foi estruturado em quatro itens, além desta introdução. No item procedimentos metodológicos consta os recursos utilizados para a produção dos dados e elaboração dos produtos cartográficos. No seguir, analisamos pressupostos da teoria da renda da terra urbana e os principais agentes responsáveis pelas transformações nos usos do solo. No penúltimo item focalizamos sobre a expansão territorial urbana recente em Presidente Prudente e os resultantes sobre a morfologia urbana. Nas considerações finais, retomamos aspectos discutidos no artigo e lançamos ideias de aprofundamento dos estudos.

\section{PROCEDIMENTOS METODOLÓGICOS}

A produção dos dados que subsidiou a elaboração cartográfica teve como recorte temporal os anos de 2010 e 2018. Para a vetorização dos tipos de loteamentos e lotes não edificados em 2010, utilizamos ortofotos aéreas de alta resolução disponibilizada pela Empresa Paulista de Planejamento Metropolitano (EMPLASA), imagem referente ao mês de julho. Para 2018, utilizamos imagem de satélite disponível no Google Earth Pro, referente a cena imageada em julho. Excluímos do mapeamento os lotes não edificados situados nos loteamentos residenciais fechados, pois não faziam parte do escopo da pesquisa, e nos loteamentos de chácaras devido à dificuldade de vetorizar com precisão os limites dos lotes, pois as áreas edificadas são reduzidas.

Realizamos pesquisa de campo para aferição da delimitação dos loteamentos de chácaras, tipos de usos do solo e infraestruturas existentes. As plantas dos loteamentos existentes na prefeitura municipal serviram para periodizar a implantação dos empreendimentos. Nos loteamentos de chácaras ilegais, a prefeitura não dispõe das plantas, o que comprometeu a acurácia do ano de criação dos loteamentos, por isso indicamos por décadas.

Para a delimitação dos vazios urbanos e áreas institucionais, utilizamos um mapa digital da malha urbana de Presidente Prudente e do cadastro de contribuintes proprietários de imóveis. Cruzamos os dados a partir de códigos numéricos existentes nos documentos e vetorizamos os polígonos dos imóveis sobre uma ortofoto (2010) e imagem de satélite de alta resolução (2018), distinguindo as propriedades particulares das públicas, que permitiram construir a tipologia.

Para os imóveis rurais, no aspecto jurídico, pertencentes às empresas de incorporação imobiliária, os dados foram catalogados no Sistema Nacional de Cadastro Rural (SNCR) gerenciado pelo Instituto Nacional de Colonização e Reforma Agrária (INCRA). Tabulamos os dados, separando para determinados imóveis as frações pertencentes a cada empresa, pois em alguns imóveis rurais existe a copropriedade. Após esta etapa, somamos as frações que as empresas detêm nos imóveis e calculamos o total de terras em hectare que possuem no município. Essa fonte de dados possibilita

$\begin{array}{lllll}\text { Caminhos de Geografia } & \text { Uberlândia-MG } & \text { v. 22, n. } 83 & \text { out./2021 } & \text { p. 200-218 Página } 201\end{array}$


compreender como esses agentes se antecipam e formam bancos de terras para monopolizar ou influenciar determinados vetores de expansão urbana e como o poder público local atua para beneficiar os detentores da terra através da ampliação do perímetro urbano, que permite converter o solo de rural para urbano.

\section{A RENDA DA TERRA URBANA E OS AGENTES PRODUTORES DA CIDADE}

A terra é um bem natural, mas no sistema capitalista foi transformada em mercadoria, tornando-se componente essencial da lógica de reprodução do capital. A mercadoria terra é um dos elementos imprescindíveis na produção das cidades por meio da conversão da terra rural em urbana, sendo que sua inserção no mercado fundiário é realizada com a interveniência de um conjunto de agentes (ABRAMO, 1989; POLANYI, 2000).

Para o entendimento dos agentes que produzem o espaço urbano, a teoria da renda da terra é marco importante. Marx (2016) fundamentou os postulados da teoria geral da renda da terra ao expor diferentes formas que a renda assume na sociedade capitalista em função da propriedade privada da terra. Essa teoria teve sua concepção elaborada para o entendimento da terra rural em relação à atuação dos proprietários fundiários e dos capitalistas agrícolas. No século XX, foi adotada por outros autores, que aplicaram seus pressupostos para o caso urbano. Surgiu uma variação dessa teoria ao incorporar novas facetas, decorrentes das transformações nas relações capitalistas e especificidades que a análise requer para a abordagem da terra urbana e das relações no ambiente construído para a circulação do capital (JARAMILLO, 2009; HARVEY, 2013).

Jaramillo (2009) avançou na abordagem teórica e na proposição de uma releitura para a construção de uma teoria da renda da terra urbana. Ele utiliza as mesmas categorias de renda existentes em Marx (2016). Todavia, introduz dois subgrupos de rendas para a análise no contexto urbano: rendas primárias, que estão relacionadas à produção do ambiente construído urbano, após a conversão do uso da terra rural em urbana; rendas secundárias, vinculadas ao consumo do ambiente urbano, seja para atividades de reprodução do capital e/ou para reprodução da classe trabalhadora.

A incorporação de elementos dessa teoria para o espaço urbano possibilita o entendimento não apenas da dimensão da propriedade privada da terra, como também permite articular com a dimensão social e política na construção da cidade, e por quais meios as diferentes classes sociais produzem e se apropriam dos diferentes espaços. Acrescenta-se como os agentes fundiários/imobiliários produzem diferenciações no espaço urbano para ampliar rendas (BARCELLA e MELAZZO, 2020).

A propriedade privada da terra gera implicações para além do urbano ou do econômico, visto a dimensão social e política de como a sociedade constrói a cidade e quais espaços são direcionados para as diferentes classes sociais. Há implicações políticas de como se estruturam e se redefinem as localizações dos sujeitos na cidade, reforçando, portanto, a importância do entendimento dos agentes econômicos e do Estado como produtores dessas diferenciações (SMOLKA, 1987; SPOSITO, 1990).

Pesquisas usando a abordagem da teoria da renda da terra urbana foram realizadas por Sposito (1990) e Sposito (1991) que analisaram dimensões vinculadas à morfologia urbana. O primeiro autor abordou a expansão territorial urbana, na perspectiva horizontal, com a renda diferencial sendo formada ao converter-se solo rural em urbano. O segundo trata da formação da renda diferencial e de monopólio, ao verticalizar-se sobre determinados terrenos, num mecanismo de produção do solo criado, que denominou de reprodução territorial ampliada, em que fatores locacionais, escassez relativa de terrenos e dimensões simbólicas são fundamentais para reforçar o processo de verticalização.

A cidade, na contemporaneidade, deve ser entendida como espaço e mercadoria, pois suas parcelas de terra são compradas, especuladas e vendidas como qualquer outra mercadoria, com a especificidade de que a terra carrega consigo outros atributos, tais como a localização e as qualidades físicas (MUMFORD, 2008; HARVEY, 2013). A propriedade privada do solo na cidade possibilita para

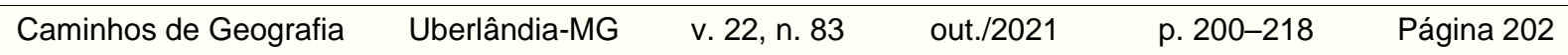


seu proprietário a extração de renda, tendo em vista os aspectos físicos, o ambiente construído, localização e atributos socioeconômicos (JARAMILLO, 2009).

Para Capel (2013), os agentes produtores do espaço urbano são os que têm capacidade para intervir na construção da cidade, destacando-se os proprietários de terras, dos meios de produção, incorporadores imobiliários, construtores e o Estado. Contrapõem-se aos atores, que são os indivíduos e grupos sociais presentes na cidade, que vivem e se movem nela. Estes, dependendo da forma como se organizam, podem transformar-se em agentes, em determinado contexto. Agentes e atores produzem o ambiente construído urbano e as relações que nele se efetivam.

O ambiente construído urbano é formado pelo conjunto de infraestruturas, edificações privadas e públicas, isto é, o lócus de substanciais imobilizações financeiras na forma de capital fixo de longa duração, que são parte das lógicas de produção e consumo urbano (SMOLKA, 1987). A terra também se constitui em um tipo de capital fixo (HARVEY, 2013), nisso a importância da antecipação de inversões para garantir sua apropriação pelo capital incorporador, visando a produção imobiliária posterior (BARCELLA e MELAZZO, 2020).

A apropriação de terras rurais é parte do processo relacionado à produção do espaço urbano. Singer (1978), Smolka (1987) e Abramo (1989) ao tratarem dos agentes produtores da cidade, vinculam a modificação no tipo de uso do solo de rural para urbano, para os quais a formação e apropriação da renda da terra é componente nessa conversão. Os ganhos fundiários são imprescindíveis nos processos de produção da cidade na contemporaneidade. De tal modo, o agente incorporador tende a apropriar-se de parcelas de terras para ampliar suas rendas ao transformar os usos do solo.

Abramo (1989) caracteriza o capital incorporador como um "maestro" do circuito imobiliário ao organizar os potenciais usos do solo urbano, que requerem que o agente construtor consolide a transformação nos usos ao edificar. Para a produção do ambiente construído urbano atua um conjunto de agentes que buscam, a partir de suas ações, conquistar maior parcela dos lucros na produção imobiliária.

\begin{abstract}
Assim, os capitais incorporadores, por disporem de solo urbano e necessitarem de um processo de construção para operar sua mudança de uso, articulam-se com os capitais construtores, que necessitam de solo para iniciarem seu ciclo reprodutivo. Nesse sentido, os capitais construtores estão subordinados à lógica de valorização dos capitais incorporadores. Como necessitam do solo para operar seu processo de valorização, não possuem autonomia sobre decisões de produzir, dependendo das decisões dos capitais incorporadores em operarem mudanças de uso do solo (ABRAMO, 1989, p. 49).
\end{abstract}

Ao situar a atuação dos agentes incorporadores, é imprescindível vincular outros dois agentes na etapa de transformação nos usos do solo: os proprietários fundiários e o Estado. O primeiro exerce papel fundamental ao relacionar-se com o capital incorporador, comercializando sua terra ou cedendo direitos para ter participação no resultado do empreendimento fundiário/imobiliário a ser implantado. Porém, há entre eles disputas pertinentes sobre qual montante de renda da terra cada agente se apropriará, pois, caso não seja vantajoso para o proprietário fundiário participar do processo de parcelamento da terra rural para urbana, ou seja, a parte da renda diferencial de que o agente incorporador irá apropriar-se, não o fará. Dessa forma, a associação ou disputa entre esses agentes envolve dimensão especulativa sobre rendas futuras da terra e que influenciam na morfologia urbana (SMOLKA, 1987; SPOSITO, 1990).

O Estado tem papel relevante por ser portador da legitimidade jurídica para regulamentar as transformações nos usos do solo ao impor prerrogativas que dificultam a atividade de incorporação por qualquer indivíduo ou mesmo ser um agente que potencializa as práticas de extração da renda da terra por proprietários fundiários e incorporadores. Além disso, possui a prerrogativa de delimitar e ampliar o perímetro urbano, área jurídica, onde o parcelamento do solo pode ser realizado em metros quadrados; implementar normas como zoneamento do uso e ocupação do solo; e atuar nas escolhas

$\begin{array}{lllll}\text { Caminhos de Geografia } & \text { Uberlândia-MG } & \text { v. 22, n. } 83 & \text { out./2021 } & \text { p. 200-218 Página } 203\end{array}$


locacionais dos conjuntos habitacionais populares, que influenciam os vetores de expansão territorial urbana e podem ampliar as diferenciações socioespaciais entre áreas da cidade.

Dentre as funções significativas do Estado está a capacidade de prover infraestruturas urbanas de forma desigual sobre o espaço, criando ou aumentando a acessibilidade de certas localidades que tende a valorizar os terrenos adjacentes, ou mesmo, produzindo conjuntos habitacionais em áreas afastadas da malha urbana compacta. Ao implantar as infraestruturas necessárias para esses moradores, tais como serviços de abastecimento de água, rede de coleta de resíduos domésticos, vias pavimentadas e linhas de ônibus, valoriza um conjunto de terras não urbanizadas ao longo dos eixos viários, que então são especuladas (SINGER, 1978; VILLAÇA, 2001).

Diferentes agentes participam na produção do espaço urbano. Contudo, há distinção na escala de atuação, pois às suas práticas ocorrem de forma intencional, em escalas que variam segundo porte econômico, capacidade de influência política sobre as instituições do Estado e lógicas que os norteiam. Os agentes incorporadores podem atuar desde a escala de um bairro com certas especificidades de clientes, na abertura de loteamentos com padrões diferentes ou mesmo no âmbito da cidade, promovendo sua reestruturação (SPOSITO, 2005).

A compreensão dos principais agentes produtores da cidade e de como a renda da terra urbana vinculase a disputa sobre as lógicas e direções da expansão do tecido urbano, permite analisar diferentes tipos de parcelamento do solo para fins residenciais que vêm se materializando numa forma de expansão territorial urbana caracterizada pela descontínua e com distintas morfologias em Presidente Prudente.

\section{TIPOS DE PARCELAMENTO DO SOLO E EXPANSÃO DO TECIDO URBANO}

Em relação aos tipos de parcelamento do solo urbano, a Lei Federal 6.766, de 1979, define as infraestruturas mínimas e equipamentos urbanísticos requeridos num loteamento. A área mínima do lote é de $125 \mathrm{~m}^{2}$, quando se tratar de parcelamento para habitação de interesse social. A Lei vincula o parcelamento para fins urbanos apenas nas zonas urbanas ou de expansão urbana, definidas pelo poder público municipal, que estejam situadas dentro do perímetro urbano.

A competência para legislar sobre o território rural cabe à União, de acordo com a Lei 4.504/1964 (Estatuto da Terra) e o Decreto 62.504/1968, que define exceções para parcelamento com finalidades comerciais, industriais e serviços em áreas juridicamente rurais, proibindo o parcelamento ou desmembramento de imóvel rural situado em área juridicamente rural, menor que a fração mínima de parcelamento (2 hectares ou $20.000 \mathrm{~m}^{2}$ ) para fins de loteamento urbano.

A dimensão dos lotes e as infraestruturas básicas são dois elementos que utilizamos para distinguir os tipos de parcelamento dos loteamentos residenciais implantados no município, diferenciando um terceiro que diz respeito à existência de muros, o loteamento residencial fechado.

O estudo da morfologia urbana é essencial, pois permite compreender formas e conteúdos nas áreas em urbanização, diferenciando esses espaços pelo tipo de parcelamento e usos do solo, público que se destina, além das infraestruturas mínimas, no que diz respeito ao cumprimento das normas legais sobre parcelamento. Tal fato se relaciona a preceitos do loteador em extrair rendas da terra com menor aplicação de capital fixo ou agregar atributos sociais nos loteamentos que possibilitam auferir maiores rendas (VILLAÇA, 2001; JARAMILLO, 2009; CAPEL, 2013).

A análise da morfologia relacionada à dimensão dos lotes, infraestruturas e densidade populacional, possibilitou diferenciar três tipologias de loteamento: a) loteamento aberto, com área do lote geralmente inferior a $400 \mathrm{~m}^{2}$ e onde os equipamentos de infraestrutura básica foram implantados pelo agente

$\begin{array}{lllll}\text { Caminhos de Geografia } & \text { Uberlândia-MG } & \text { v. 22, n. } 83 & \text { out./2021 } & \text { p. 200-218 Página } 204\end{array}$


incorporador ou pelo Estado; b) loteamento de chácara, os lotes têm dimensões de $700 \mathrm{~m}^{2}$ até 5.000 $\left.\mathrm{m}^{2} ; \mathrm{c}\right)$ loteamento residencial fechado.

Os loteamentos fechados estão produzindo uma nova forma no tecido urbano, resultando numa lógica peculiar de expansão territorial urbana nas décadas recentes, caracterizada pela descontinuidade e consubstanciando novas práticas espaciais dos moradores com a cidade (SPOSITO e GÓES, 2013).

As diferentes tipologias de loteamentos estão vinculados à apropriação da renda da terra, em que a margem de retorno do capital aplicado é fundamental, na medida em que o agente incorporador ou em certos casos o proprietário fundiário busca produzir e apropriar-se da renda diferencial ao converter o uso do solo de rural para urbano. O Estado também assume papel de indutor da expansão do tecido urbano ao implantar ou financiar loteamentos e conjuntos habitacionais direcionados à população de baixa renda (OLIVEIRA, 2015; SANTOS, 2020).

O parcelamento da terra em unidades menores para a implantação de loteamentos fechados, em determinados casos, pode ocasionar a formação da renda de monopólio, ou segundo Jaramillo (2009), renda de monopólio de segregação. A capacidade financeira do agente é um dos principais elementos relacionados ao tipo de loteamento e das infraestruturas implantadas, porquanto, influencia de forma direta a apropriação da renda da terra (ABRAMO, 1989).

Os loteamentos residenciais fechados são um tipo de produto fundiário/imobiliário em expansão no Brasil. Sposito e Góes (2013) denomina-os como espaços residenciais fechados, empreendimentos que são murados e controlados por sistemas de segurança, no qual o incorporador comercializa o lote ou a residência, associando um conjunto de atributos (segurança, lazer, status e direito à exclusividade) e maximizando a renda da terra ao longo do tempo através da administração do espaço. Além disso, vem modificando a relação dos moradores com a cidade ocasionando, em determinados contextos, a ampliação da diferenciação e até da fragmentação socioespacial.

Nos loteamentos residenciais fechados ocorrem dois momentos de renda diferencial, sendo o primeiro quando há a conversão da terra rural em lotes urbanos, e o segundo vinculado aos produtos ofertados aos moradores, relacionados à exclusividade de residirem num loteamento e não em outro. Entra em cena uma complexidade do sentido de morar na cidade e, mais precisamente, em determinados lugares da cidade, ou seja, os elementos locacional e simbólico são facetas importantes para essas novas formas de habitat, fato que pode formar uma renda de monopólio para o agente incorporador, visto a elevada seletividade socioeconômica para residir em alguns desses loteamentos fechados (SPOSITO e GÓES, 2013).

Em Presidente Prudente, Sposito (1990) analisou transformações de terras rurais em urbanas. Enfatizou a relação entre poder público local e proprietários fundiários na abertura de um conjunto de loteamentos irregulares (do ponto de vista legal) até o final da década 1970, associado também à implantação de infraestrutura de forma desigual no território. O processo foi especulativo visando à concentração da renda fundiária urbana por serem os loteamentos descontínuos do tecido urbano existente. A partir da década de 1980, houve modificação na lógica de produção da cidade, com a maior participação de agentes capitalistas especializados, elevando a capacidade de atuação sobre as direções que a área urbana deveria expandir, ao implantarem dezenas de loteamentos.

Disso resulta que a forma urbana na contemporaneidade pode apresentar-se concentrada ou dispersa. Sposito (2005) indica que a cidade pode crescer de forma contínua através do prolongamento dos loteamentos já constituídos ou descontínua, quando os novos loteamentos são distantes da malha urbana existente, e para os quais um conjunto de infraestruturas de serviços públicos (transporte, rede de água, esgotos, energia, comunicação) devem ser implantados. Distingue a descontinuidade territorial do tecido urbano em relação à continuidade espacial. A primeira expressão conforma a constituição de terras não-urbanas, entre os novos loteamentos e o tecido urbano existente; a segunda, denota o prolongamento das infraestruturas e a atuação dos sujeitos relativos à capacidade econômica,

$\begin{array}{lllll}\text { Caminhos de Geografia } & \text { Uberlândia-MG } & \text { v. 22, n. } 83 & \text { out./2021 } & \text { p. 200-218 Página } 205\end{array}$


à acessibilidade e às interações. Dinâmicas nas formas e nos processos que resultam no aumento dos custos econômicos para deslocamentos nas áreas de baixa densidade, além de contribuir para a valorização fundiária entre as áreas.

O par descontinuidade territorial e continuidade espacial são importantes para o entendimento de como a terra e as lógicas dos incorporadores fundiários/imobiliários vêm atuando para produzir e redefinir os contornos da cidade.

O aumento da mobilidade espacial para um segmento da população possibilita maior acessibilidade, pois o sentido de residir próximo ou distante do centro é influenciado pela capacidade econômica. As distâncias são relativizadas pelo tempo, considerando o tipo de transporte, a qualidade e densidade das vias de circulação e a capacidade econômica para arcar com os custos do deslocamento. Para uns, a distância implica em menor mobilidade espacial ou de acessibilidade a certas áreas da cidade devido ao aumento dos custos (VILLAÇA, 2001).

No que concerne aos loteamentos de chácaras em Presidente Prudente, voltados para primeira ou segunda residências, o primeiro empreendimento data de 1982, quando o agente incorporador Imoplan Residência, Comércio, Construção e Incorporação de Imóveis Ltda. submeteu à prefeitura municipal o projeto de loteamento denominado Terras de Imoplan, no setor sudeste do município. Os demais datam do final dos anos 1990 e início da década seguinte.

Não pudemos determinar o ano em que cada loteamento foi efetivado pelo fato de alguns serem ilegais, isto é, o incorporador ou o proprietário fundiário responsável pelo loteamento não submeteu o projeto de parcelamento à aprovação da prefeitura municipal e, de modo complementar, as terras parceladas encontravam-se em área juridicamente rural, não sendo de competência exclusiva da esfera municipal legislar sobre elas. Disso resulta parte de sua ilegalidade.

A Lei Complementar no 231/2018 dispõe sobre o Zoneamento de Uso e Ocupação do Solo no município, estabeleceu áreas denominadas de zona de usos especiais, onde são possíveis determinadas atividades, dentre as quais é permitindo o parcelamento do solo para a implantação dos loteamentos de chácaras, exigindo tamanho mínimo do lote de $2.000 \mathrm{~m}^{2}$. Essa norma visa disciplinar futuros empreendimentos desse tipo.

No âmbito jurídico, a ilegalidade do loteamento de chácaras em área juridicamente rural (fora do perímetro urbano) não permite ao incorporador ou agente registrar no Cartório de Registro de Imóveis o empreendimento, consequentemente, o comprador do lote assina apenas um contrato de compra e venda, não tendo escritura do imóvel adquirido. Como meio de burlar a legislação federal, a propriedade pode ocorrer na forma condominial, ou seja, os proprietários passam a ter fração do empreendimento e a propriedade permanece como único imóvel.

O agente que fez a transformação no uso da terra, em alguns casos, foi o próprio proprietário da gleba, que por não seguir as exigências legais no que concerne aos custos de elaboração de projeto urbanístico, pagamento de licenças e autorizações, além da implantação das infraestruturas básicas, investiu um capital pequeno para abertura das vias de circulação e delimitação dos lotes. O total de lotes por loteamento varia desde dezenas até centenas, o que pode estar correlacionado a capacidade econômica do agente responsável pelo empreendimento.

O parcelamento de glebas rurais com emprego de baixo capital na implantação das infraestruturas gera para o agente que realizou a incorporação um ganho fundiário expressivo. A renda diferencial se efetiva ao comercializar o lote em metros quadrados e não em hectares. Esse aspecto evidencia que a renda diferencial é produzida mediante a transformação nos usos do solo, e não apenas devido ao aporte de capital aplicado na etapa de edificação. Por isso, a importância do capital incorporador na apropriação e formação de estoques de terras (SMOLKA, 1987; SPOSITO, 1990).

A figura 1 indica o tipo de parcelamento do solo em loteamentos abertos (não hachurados), loteamentos residenciais fechados e loteamentos de chácaras em 2010. Os loteamentos de chácaras totalizavam

$\begin{array}{lllll}\text { Caminhos de Geografia } & \text { Uberlândia-MG } & \text { v. 22, n. } 83 & \text { out./2021 } & \text { p. 200-218 Página } 206\end{array}$


18, com diferentes portes, mas muito semelhantes em termos de carência de infraestruturas urbanísticas (ruas não pavimentadas, inexistência de rede de abastecimento de água potável, coleta de esgotos e de iluminação pública).

No que concerne às infraestruturas de uso coletivo (rede de água potável, coleta de resíduos cloacais e transporte público) a descontinuidade territorial reforça a precarização do acesso a infraestruturas básicas e menor acessibilidade para a população residente, notadamente aquela parcela que não dispõe de transporte particular.

Figura 1 - Presidente Prudente: tecido urbano (2010).

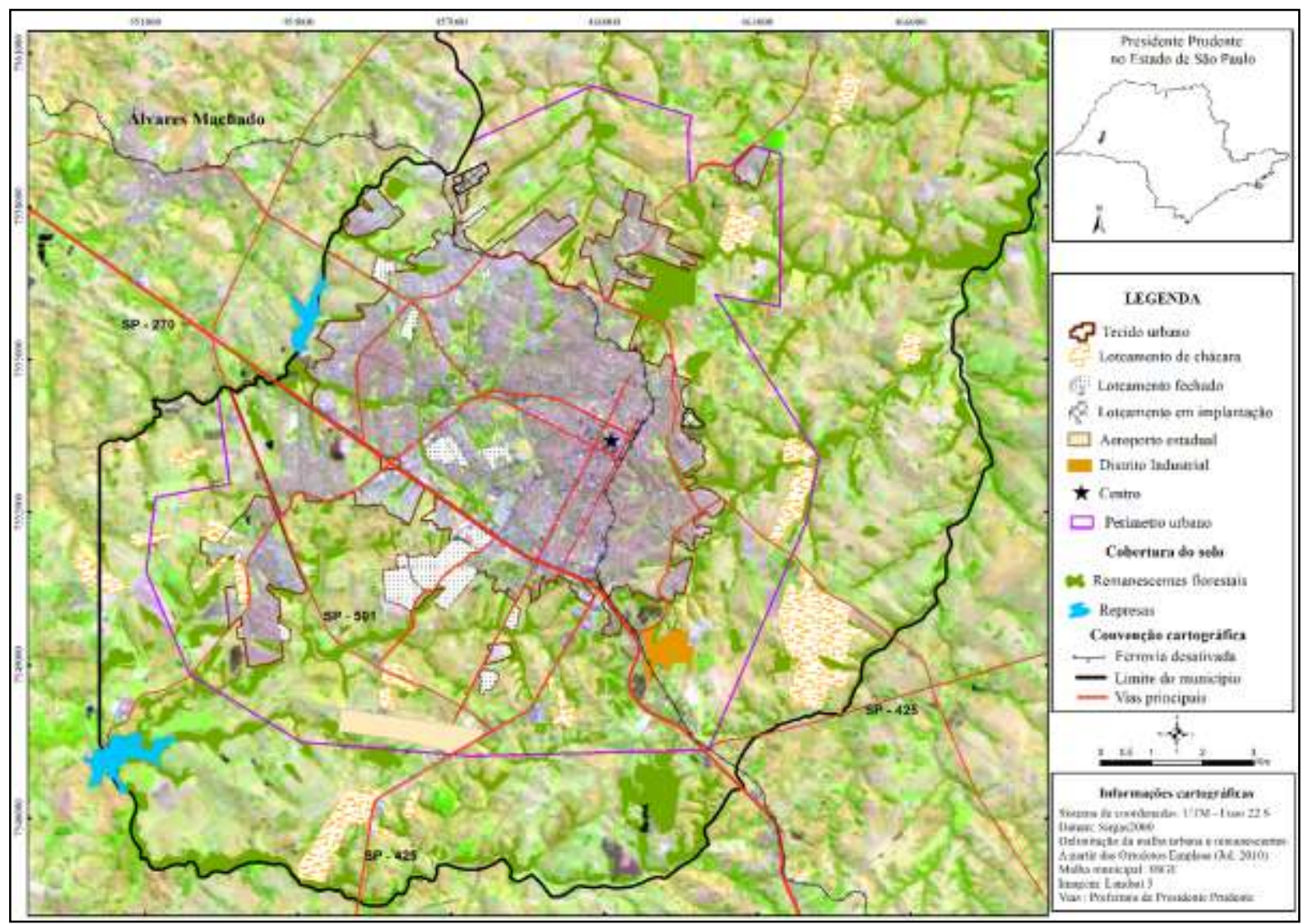

Fonte - Elaborado pelo autor (2020)

Os loteamentos de chácaras compõem dinâmica de integração mais frágil com a malha urbana, motivo que possibilita distingui-los dos loteamentos abertos e dos loteamentos fechados. Dentre os loteamentos abertos, dois encontravam-se em fase de implantação. O tecido urbano apresenta duas grandes manchas urbanas descontínuas, o bairro Morada do Sol no setor norte e o Residencial Maré Mansa e Parque Imperial no setor noroeste.

Os loteamentos fechados totalizavam 16 e estão dispersos na cidade. O primeiro empreendimento foi implantado no início da década de 1980. No setor sul, está em consolidação um vetor de expansão mediante a seletividade espacial para esse tipo de empreendimento, tendo em vista que um dos principais agentes incorporadores, o Grupo Encalso Damha, detinha cinco loteamentos fechados, além de ser proprietário de gleba rural, definindo o tipo de empreendimento fundiário/imobiliário e público alvo a residir nesse setor da cidade. Havia outros dois loteamentos fechados implantados por outros agentes incorporadores nesta área de expansão urbana. Para uma análise detalhada desses empreendimentos, ver Sposito e Góes (2013).
Caminhos de Geografia
Uberlândia-MG
v. 22, n. 83
out./2021
p. $200-218$
Página 207 
O aspecto da acessibilidade, relação entre espaço e tempo, mediada pela capacidade das classes sociais custearem o deslocamento, seja por transporte público ou particular, é fundamental para explicar a forma urbana que vem se constituindo em Presidente Prudente.

As condições de transporte conformam parte da estruturação urbana e das possibilidades dos deslocamentos, tanto em termos de tempo como dos custos relativos às famílias. A mobilidade espacial é maior para a população de alto poder aquisitivo, permitindo escolher residir na periferia da cidade, nos novos produtos fundiários/imobiliários; enquanto a população de baixa renda desloca para a periferia, onde seus rendimentos permitem ter acesso à residência (MIYAZAKI, 2008). Segundo Villaça (2001, p. 181) "de maneira geral, as camadas populares são mais prisioneiras do espaço do que as camadas de mais alta renda, pois a mobilidade dessas camadas é bem maior".

A descontinuidade do tecido urbano está fundamentada em conteúdos relacionados à renda da terra e das potencialidades de mobilidade dos indivíduos. Resulta em áreas não parceladas denominadas de vazios urbanos (VILLAÇA, 2001; NASCIMENTO, 2014; MAIA, 2019), apesar de existir distinções entre esses autores. Essas glebas são em Presidente Prudente, em certos casos, utilizadas para atividades agropecuárias de baixa produtividade, notadamente a pecuária bovina, mas que camuflam, no uso aparente, mecanismos de espera de "valorização" da terra.

De forma geral, nem todas as áreas não edificadas no tecido urbano são propriedade particular e estão especulando sobre a possibilidade de maior renda no futuro. Há, dentre essas áreas, propriedades pertencentes ao Estado, nos diferentes níveis, que não foram edificadas por uma série de razões: espaços voltados para as áreas de lazer, preservação dos recursos hídricos e florestais, e futura implantação de infraestruturas de uso comunitário (escolas, creches, hospitais) e repartições da administração pública. De tal modo, não devem ser rotuladas como vazios urbanos. Assim, discordamos em parte das proposições constantes em Nascimento (2014) e Maia (2019).

A figura 2 refere-se às áreas não edificadas em Presidente Prudente (2010). Para a delimitação dos vazios urbanos, consideramos as terras particulares no interior do tecido urbano em função da existência nas bordas da cidade de um conjunto de propriedades rurais com uso agropecuário, não possibilitando distinguir se os proprietários estariam especulando sobre a "valorização" das terras, processo decorrente das dinâmicas de expansão da cidade. Caracterizamos essas terras como nãourbanas, mesmo situadas no perímetro urbano, passíveis de loteamento. Além disso, são terras potencialmente urbanizáveis, mas isso dependerá de como se estruturarão os vetores da expansão urbana. Contudo, como demonstraremos mais adiante, parte dessas terras vem sendo apropriados pelo capital incorporador, formando banco de terras, objetivando assegurar o controle de áreas de expansão.

Adotamos para as terras públicas a expressão área institucional, quando se referem a espaços resultantes da cessão obrigatória pelos incorporadores das áreas ditas institucionais ou de outras formas de aquisição pelo poder público. A categoria parque é integrante da área institucional, porém, devido à dimensão, preferimos indicar seus usos prioritários. Não delimitamos as áreas das escolas, universidades, campos de futebol e praças, pois entendemos que a fração não edificada ou utilizada tem um uso potencialmente definido.

Os remanescentes florestais foram classificados à parte, porque são, predominantemente, áreas de preservação permanente (APP), localizados em terras públicas ou particulares, margeando os cursos d'água.

As maiores glebas não edificadas estão no quadrante oeste, estendendo-se até o extremo do município, no Balneário da Amizade. A imensa área que margeia o reservatório está sendo, nesta década, convertida em loteamentos fechados para população de renda média-alta.

$\begin{array}{llllll}\text { Caminhos de Geografia } & \text { Uberlândia-MG } & \text { v. 22, n. } 83 & \text { out./2021 } & \text { p. 200-218 } & \text { Página } 208\end{array}$


Figura 2 - Presidente Prudente: áreas não edificadas no tecido urbano (2010).

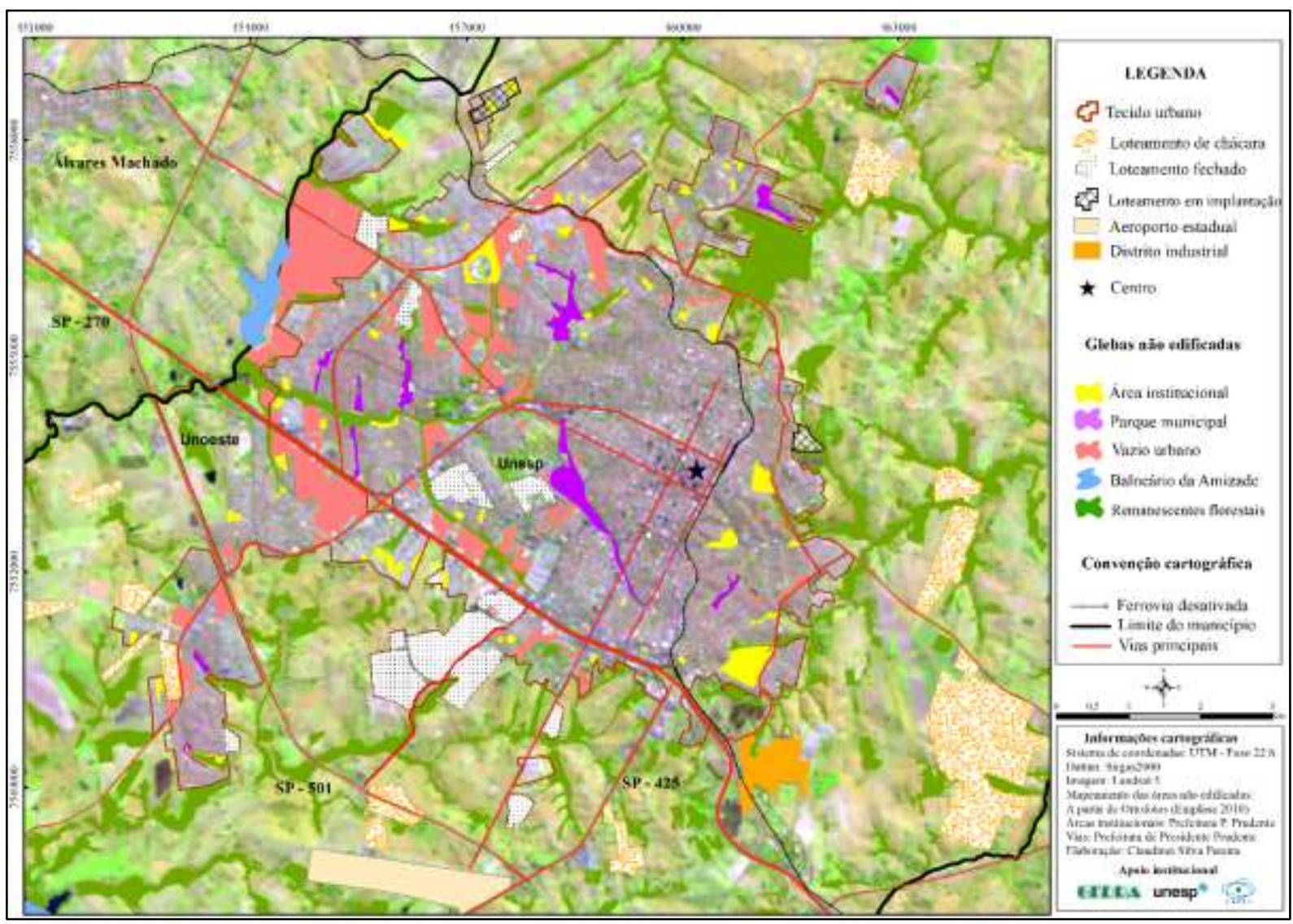

Fonte - Elaborado pelo autor (2020).

A manutenção de imóveis rurais no espaço urbano com atividades agropecuárias é permitida pela legislação, e o proprietário paga o Imposto Territorial Rural (ITR) ao invés do Imposto Predial Territorial Urbano (IPTU), caso opte e comprove a permanência no imóvel rural de atividades agropecuárias. Essa situação potencializa os mecanismos de especulação fundiária, porque a tributação incidente sobre a terra rural é irrisória quando comparada à sobre as terras urbanas. Fato que reforça a manutenção do uso do solo com pastagens para a criação de gado bovino em várias áreas que delimitamos como vazios urbanos.

O preço do terreno é fundamental nos processos de produção do ambiente construído, em que ganha importância as alterações nos seus atributos, seja por atuação dos agentes privados ou do Estado com a implantação de infraestruturas que valorizam às externalidades, definindo vantagens locacionais. Esse fator é de suma relevância, pois a partir da expectativa de valorização futura, enormes glebas ou terrenos são mantidos sem edificação no interior da cidade, tratando a terra como um ativo (ABRAMO, 1989). De tal modo, esse processo especulativo ocorre em Presidente Prudente, pois são imensas áreas deixadas sem parcelamento no tecido urbano por várias décadas.

Ao ampliarmos a escala sobre a cidade, comparece outro elemento da morfologia urbana que são os lotes não edificados, pertencem a centenas de indivíduos. São resultantes de lógicas distintas em relação ao capital incorporador ou do grande proprietário fundiário, mas que há similaridades no que concerne à terra ser também para estes indivíduos um bem patrimonial e, não necessariamente, demandam os lotes para construção da própria moradia. Este fato Sposito (1990) evidenciou ao contabilizar os detentores de terrenos em Presidente Prudente.

Em relação ao acúmulo de terras urbanas, Sayad (1977) analisou a terra como reserva de valor alternativa ao capital produtivo, isto é, dependendo das taxas de juros correntes e da taxa de retorno do capital, a aquisição da terra urbana seria um mecanismo pertinente como investimento. A

$\begin{array}{lllll}\text { Caminhos de Geografia } & \text { Uberlândia-MG } & \text { v. 22, n. } 83 & \text { out./2021 } & \text { p. 200-218 Página } 209\end{array}$


"valorização" a partir de práticas especulativas, quando a terra entra no mercado fundiário urbano decorrente da expansão urbana, possibilita que o investimento fundiário seja altamente rentável. O autor enfatiza que investir em terrenos urbanos é uma forma de internalizar no patrimônio privado todos os benefícios derivados de investimentos públicos realizados na cidade.

A figura 3 indica os lotes não edificados, totalizavam 8.715 unidades. $O$ tecido urbano expandiu de forma rápida ao longo das três décadas anteriores, mantendo no seu interior milhares de lotes não edificados. Evidenciam facetas da terra urbana como reserva de valor ou mesmo um ativo.

Os lotes não edificados estão dispersos por quase toda a cidade, exceção sobre aquelas áreas onde os loteamentos abertos foram destinados para conjuntos habitacionais, por exemplo, Conjunto Habitacional Ana Jacinta, no extremo sudoeste, e conjuntos Cecap, Cohab, Jequitibás I e II, na zona oeste. Nos bairros próximos ao centro, há lotes não edificados que são oriundos de loteamentos anteriores a década 1980. Nas bordas da malha urbana foram realizados parcelamentos nas décadas de 1990 e 2000, contendo quantidade expressiva de lotes não edificados.

Figura 3 - Presidente Prudente: lotes não edificados (2010).

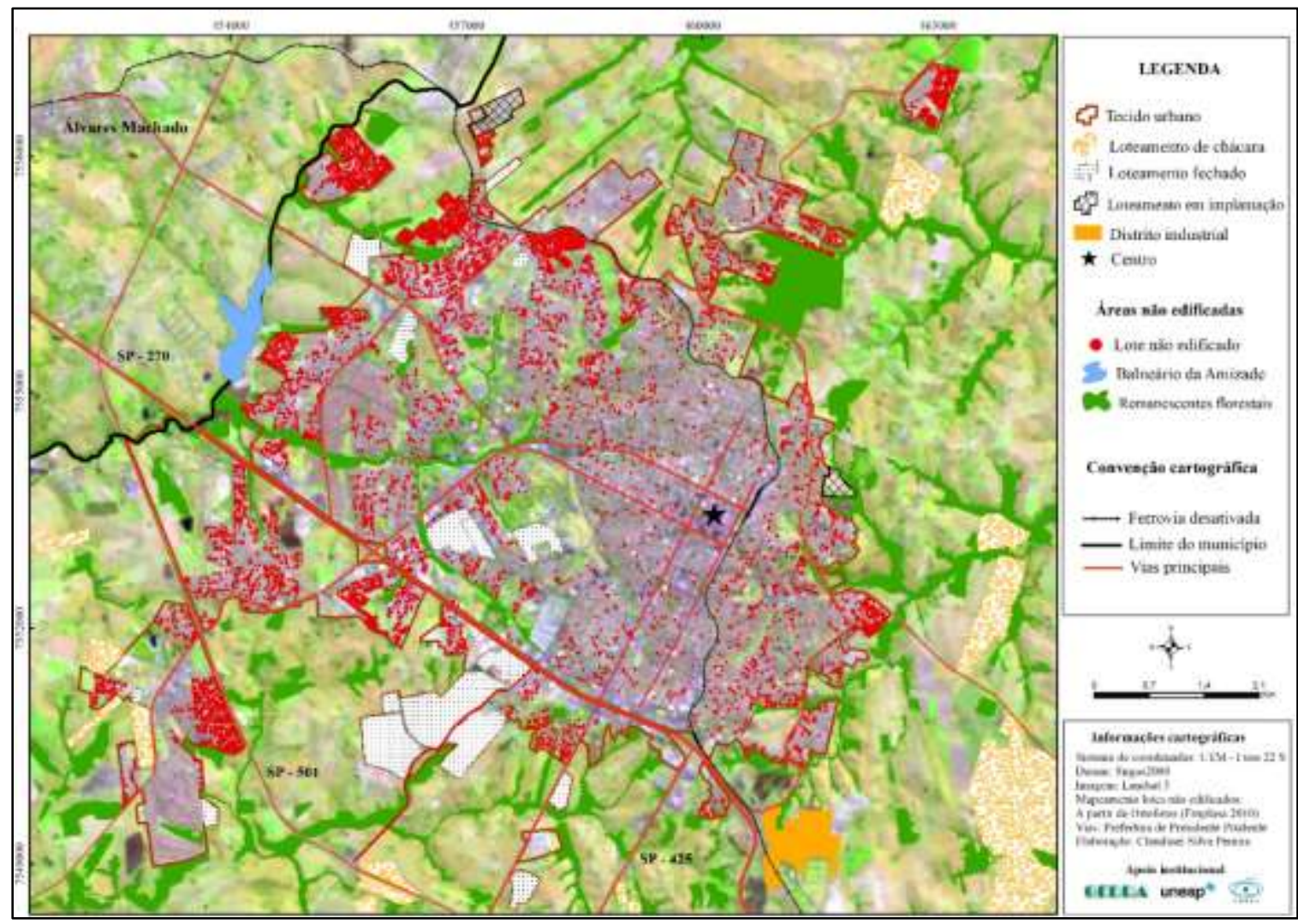

Fonte - Elaborado pelo autor (2020).

O solo urbano é cobiçado por diferentes grupos e para variadas funções (SINGER, 1978), tendo em vista que a cidade tem como principal característica a concentração de pessoas e atividades. Desse modo, a terra por estar inserida nas lógicas do sistema capitalista é apropriada de maneira privada, seus usos ou comercialização possibilitam gerar renda para seus detentores.

A localização dos terrenos/imóveis é um dos atributos espaciais diferenciais, posto que a sua valorização não se dá exclusivamente por benfeitorias realizadas pelo proprietário, mas pelo conjunto da sociedade, com destaque para as infraestruturas implantadas pelo poder público e pela escassez relativa ou absoluta em outras áreas da cidade, por efeito comparativo. A localização é o componente de valor de uso do solo produzido pelo trabalho coletivo dispendido na construção da cidade (DANIEL, 1988; VILLAÇA, 2001).

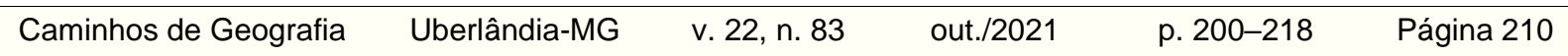


A configuração do espaço urbano no Brasil, ainda que bastante diferenciada de local para local, costuma apresentar contrastes entre os congestionamentos em áreas centrais e vazios urbanos nas periferias, ou entre os loteamentos bem servidos e aqueles mal servidos e em situação irregular. Para além do caráter inerentemente especulativo do mercado imobiliário, é preciso recordar que tal configuração é função, também, dos modos de ação e omissão (geralmente combinados) do poder político local sobre o mercado imobiliário (DANIEL, 1988, p. 29).

Com o intuito de apreender quais são os agentes detentores das terras e como influenciam nos estoques de terras não loteadas em Presidente Prudente, que podem definir vetores de expansão territorial urbana, utilizamos a base de dados do Sistema Nacional de Cadastro Rural (SNCR) do Instituto Nacional de Colonização e Reforma Agrária (INCRA), para catalogarmos os imóveis juridicamente rurais pertencentes a empresas do setor de incorporação imobiliária (Tabela 1).

Não foi possível identificar as áreas onde os imóveis estão situados, se dentro do perímetro urbano ou fora, porque no cadastro do SNCR não consta o georreferenciamento das propriedades, apesar de estar em fase de implantação esse recurso. Todavia, a base do SNCR reforça a importância de se analisar a teoria da renda da terra urbana como uma das facetas na lógica de produção da cidade contemporânea e como os agentes incorporadores antecipam estratégias de apropriação de terras, para garantir a exclusividade de empreendimentos em determinadas áreas. Fato esse evidenciado em outras realidades por Barcella e Melazzo (2020), a partir de entrevistas com os agentes de incorporação.

Tabela 1 - Presidente Prudente: empresas incorporadoras proprietárias de terras (2018).

\begin{tabular}{|c|c|c|}
\hline Empresas & Imóveis* & $\begin{array}{c}\text { Área } \\
\text { hectares }\end{array}$ \\
\hline Imovix empreendimentos imobiliários Ltda. & 1 & 3,6 \\
\hline Contrinvest construtora e comércio Ltda. & 1 & 4,5 \\
\hline Oliveira administração participação empreendimentos imobiliários Ltda. & 2 & 5,6 \\
\hline Golden fam incorporação e administração de bens Ltda. & 1 & 5,8 \\
\hline Sodemco soc empr const Oeste Paulista Ltda. & 1 & 6,3 \\
\hline Lwm incorporações imobiliárias Ltda. & 1 & 7,2 \\
\hline Construtora J. Sogame Ltda. & 1 & 7,3 \\
\hline Rancharia empreendimentos imobiliários Ltda. & 2 & 9,3 \\
\hline Caranda loteadora e incorporadora Ltda. & 1 & 9,4 \\
\hline Flamboyant empreendimentos imobiliários Ltda. & 3 & 9,8 \\
\hline Incorporadora Leonardi Ltda. & 1 & 10,2 \\
\hline Ubata Empreendimentos Imobiliários e lazer Ltda. & 1 & 12,8 \\
\hline Incorporadora Satélite Ltda. & 1 & 14,1 \\
\hline Gs Administradora de bens imóveis Ltda. & 2 & 16,3 \\
\hline Invest incorporações imobiliária Ltda. & 1 & 16,9 \\
\hline Real prime incorporações, participações e investimentos Ltda. & 1 & 17,8 \\
\hline Imobiliária do Pontal de Presidente Prudente Ltda. & 2 & 27,1 \\
\hline Our House empreendimentos e participações Ltda. & 1 & 27,8 \\
\hline Cas Construtora Ltda. & 1 & 32,4 \\
\hline União do Mandaguari empreendimentos imobiliários Ltda. & 1 & 35,1 \\
\hline Construmaya Constr. Eng. e empreendimentos Ltda. & 4 & 39,4 \\
\hline Incorporadora Bongiovani s/c Ltda. & 1 & 45,8 \\
\hline Protenge Urbanismo Ltda. & 5 & 50,7 \\
\hline Incorporadora Mampei Funada. & 5 & 54,0 \\
\hline AA Incorporadora SS Ltda. & 1 & 57,0 \\
\hline J.R.M. incorporações e construções Ltda. & 2 & 83,6 \\
\hline LLPP Incorporação Ltda. & 2 & 85,7 \\
\hline AD empreendimentos imobiliários Ltda** & 5 & 127,9 \\
\hline Terra Nova Rodobens incorporação imobiliária. & 5 & 141,9 \\
\hline Pauma empreendimentos imobiliários Ltda. & 9 & 144,5 \\
\hline Ita Cons. Imobiliária $\mathrm{AS}^{\star * \star}$ & 1 & $1.815,0$ \\
\hline \multicolumn{2}{|l|}{ Área total dos imóveis em hectares } & $2.924,4$ \\
\hline
\end{tabular}

Fonte - INCRA - Sistema Nacional de Cadastro Rural (SNCR), 2018.

* Alguns imóveis são em copropriedade com outra empresa. Nesses casos, subtraímos a fração de área da empresa no imóvel. **Empresa pertencente à família Damha, controladora do Grupo Encalso-Damha urbanizadora. ${ }^{* * *}$ Proprietária da Fazenda Baixio de Santo Ignácio.

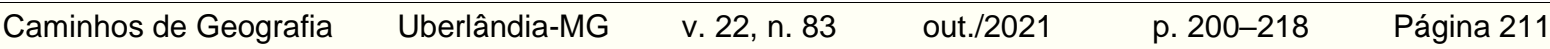


No caso da $A D$ empreendimentos imobiliários, pertence à família controladora do Grupo EncalsoDamha, de capital local, responsável por loteamentos residenciais fechados de médio-alto padrão no setor sul da cidade. Enquanto a Incorporadora Bongiovani pertence a uma família local que foi responsável por grandes loteamentos abertos na cidade, destacando os bairros Bongiovani e Novo Bongiovani.

Os agentes incorporadores tendem a apropriar-se de parcelas de terras com a intencionalidade de especular e monopolizar determinados vetores de expansão urbana. Fato atrelado a sua vinculação e influência sobre o poder público local, que ao ampliar o perímetro urbano, adequa às normas jurídicas em benefício desses agentes e de outros proprietários fundiários (DANIEL, 1988).

Proprietários de terras articulam-se ou subordinam-se a empresas de incorporação para exercerem o controle sobre as áreas de possível expansão urbana. A terra transmutou-se numa nova etapa nas relações mercantis, evidenciada pela financeirização da riqueza fundiária/imobiliária. Ao vincular-se ao capital financeiro, vem modificando as lógicas e intercalando escalas dos agentes na produção da cidade.

Melazzo (2013) analisou o processo de abertura de capitais das empresas imobiliárias na bolsa de valores no Brasil, resultando em mudanças nas lógicas de produção das cidades. Dessa maneira, a disputa pela renda da terra entre o proprietário fundiário e o agente incorporador não se efetiva apenas no momento da implantação do loteamento, pois uma prática que vem ocorrendo é a constituição de banco de terras (land bank) por incorporadores. Eles deixam-nas sem lotear por longo período, esperando o momento mais propício para lançar um produto fundiário/imobiliário, permitindo utilizar o estoque de terras para capitalizar a empresa, principalmente aquelas com capital aberto na bolsa de valores. A terra muda suas características no contexto da economia brasileira.

Da terra rural e urbana como status, símbolo do poder político, bem raiz e reserva de valor à terra como ativo de valor capaz de alavancar a acumulação e lastrear processos econômicos, urbanos e da cidade e daí à terra associada ao capital financeiro, sincronizada com seus movimentos e lógicas (MELAZZO, 2013, p. 34).

Parcela dos estoques de terras na malha urbana ou no entorno da cidade são de propriedade de empresas de incorporação que podem, através da articulação com outros agentes político/econômicos locais, influenciar nos vetores de expansão e nas tipologias dos loteamentos e públicos residentes. A ampliação do perímetro urbano é uma das facetas do jogo de interesses, em que as terras, que pela legislação não poderiam ser loteadas, passam a ser. A última ampliação do perímetro urbano em Presidente Prudente ocorreu em 2013. Entre os anos de 1990 e 2013, o perímetro urbano foi ampliado sete vezes (SANTOS, 2020), o qual incorporou loteamentos de chácaras e um conjunto de imóveis rurais, que de forma direta beneficiou os agentes incorporadores.

A figura 4 indica o tecido urbano em 2018, com os tipos de parcelamento do solo e os novos loteamentos em implantação, que reforçam o processo de expansão do tecido urbano descontínuo. Implantou-se um loteamento aberto denominado Residencial José Rena, no setor sudeste, no qual iniciava a edificação de alguns lotes. No setor sul, a ampliação do perímetro urbano visa possibilitar a regularização fundiária dos loteamentos de chácaras e ampliar a área potencialmente urbanizável.

No setor norte, a ampliação do perímetro urbano está relacionada à construção dos conjuntos habitacionais João Domingos Netto, Residencial Tapajós, Residencial Bela Vista e Residencial Cremonezi vinculados ao Programa Minha Casa, Minha Vida. Esses loteamentos somam mais de 3 mil unidades habitacionais (SANTOS, 2020). A partir da expansão do tecido neste setor com moradias direcionadas à população de baixa renda construídas pelo Estado, outros agentes incorporadores vêm implantando loteamentos abertos para o público de menor poder aquisitivo.

Os loteamentos fechados aumentaram de 16 em 2010 para 32 em 2018. Há diferenças em termos de área total ocupada e público residente entre os loteamentos fechados que surgiram a partir de programas habitacionais como o Programa de Arrendamento Residencial e o Programa Minha Casa, Minha Vida (OLIVEIRA, 2015), em relação aos direcionados à população de poder aquisitivo médio-

$\begin{array}{lllll}\text { Caminhos de Geografia } & \text { Uberlândia-MG } & \text { v. 22, n. } 83 & \text { out./2021 } & \text { p. 200-218 Página } 212\end{array}$


alto. Nestes, o incorporador atuou na produção do loteamento e alguns na construção das residências, mas prevalece o tipo em que são os proprietários dos lotes que edificam via contratação de pequenas empresas construtoras ou contratação direta de mão de obra (SPOSITO e GÓES, 2013). Enquanto nos primeiros, predomina a construção das residências padronizadas em lotes pequenos pelo agente responsável pelo empreendimento.

Figura 4 - Presidente Prudente: tecido urbano (2018).

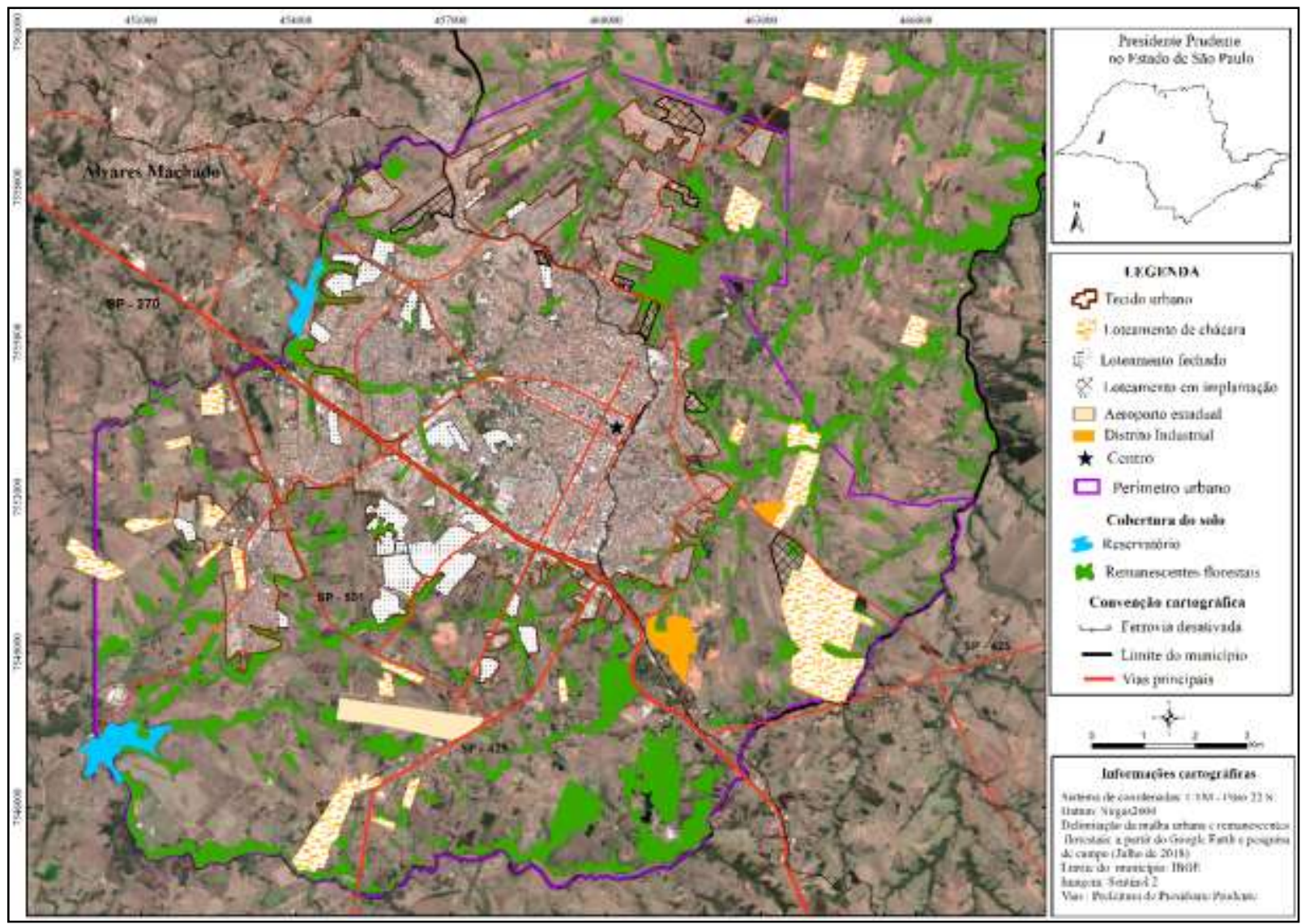

Fonte - Elaborado pelo autor (2020).

Para maximizar a renda diferencial da terra, o capital incorporador atua na produção da cidade promovendo, juntamente com o Estado, a diferenciação socioespacial ao reforçar que determinados espaços ou áreas da cidade sejam dotados de certos atributos urbanos e simbólicos em relação aos demais. A diferenciação é um meio e um produto que amplia a renda diferencial dos lotes urbanos, porque quanto maior a diferenciação socioespacial na cidade, mais o capital utiliza-se desta realidade para reforçar os atributos sociais e simbólicos da área que comercializa, podendo angariar mais renda da terra por efeito comparativo (JARAMILLO, 2009).

No setor sul, a partir do aumento de loteamentos fechados, os agentes incorporadores com a anuência do poder público municipal vêm reforçando a seletividade socioespacial com população de maior poder aquisitivo (SPOSITO e GÓES, 2013). O grupo Encalso-Damha, que em 2010 detinha cinco loteamentos fechados, construiu mais dois. Enquanto outros incorporadores, dentre eles, a Incorporadora Mampei Funada possuía quatro loteamentos fechados para população de médio-alto poder aquisitivo, sendo dois no setor sul, além de outros empreendimentos nos segmentos de edifícios verticais (residenciais e comerciais), loteamentos abertos e conjuntos habitacionais distribuídos pela cidade. A incorporadora Mampei Funada tem seus capitais oriundos do setor industrial, pois a empresa Funada atua no ramo de refrigerantes desde 1947 em Presidente Prudente e a partir de 2001, diversificou seu capitais para

$\begin{array}{llllll}\text { Caminhos de Geografia } & \text { Uberlândia-MG } & \text { v. 22, n. 83 } & \text { out./2021 } & \text { p. 200-218 } & \text { Página } 213\end{array}$


o setor imobiliário ao implantar um loteamento aberto na cidade, posteriormente ampliou o mix de produtos fundiários/imobiliários (informações extraídas do site da empresa).

A área oeste consolidou-se com loteamentos fechados ao longo da Avenida Salim Farah Maluf, conhecida popularmente como estrada da Amizade, via que conecta as cidades de Presidente Prudente e Álvares Machado, e as margens do Balneário. Estruturada por parte dos incorporadores, apresenta seletividade socioespacial, definindo um segundo vetor de expansão com esta tipologia de empreendimentos na cidade.

Em relação aos vazios urbanos (Figura 5), houve redução das áreas, muito em função da implantação de loteamentos fechados e loteamentos abertos sobre as terras que estavam com usos agropecuários, principalmente com pecuária bovina extensiva. Enquanto os conjuntos habitacionais populares na área norte, e loteamentos abertos em implantação, reforçaram em algumas áreas a descontinuidade territorial.

Figura 5 - Presidente Prudente: áreas não edificadas no tecido urbano (2018).

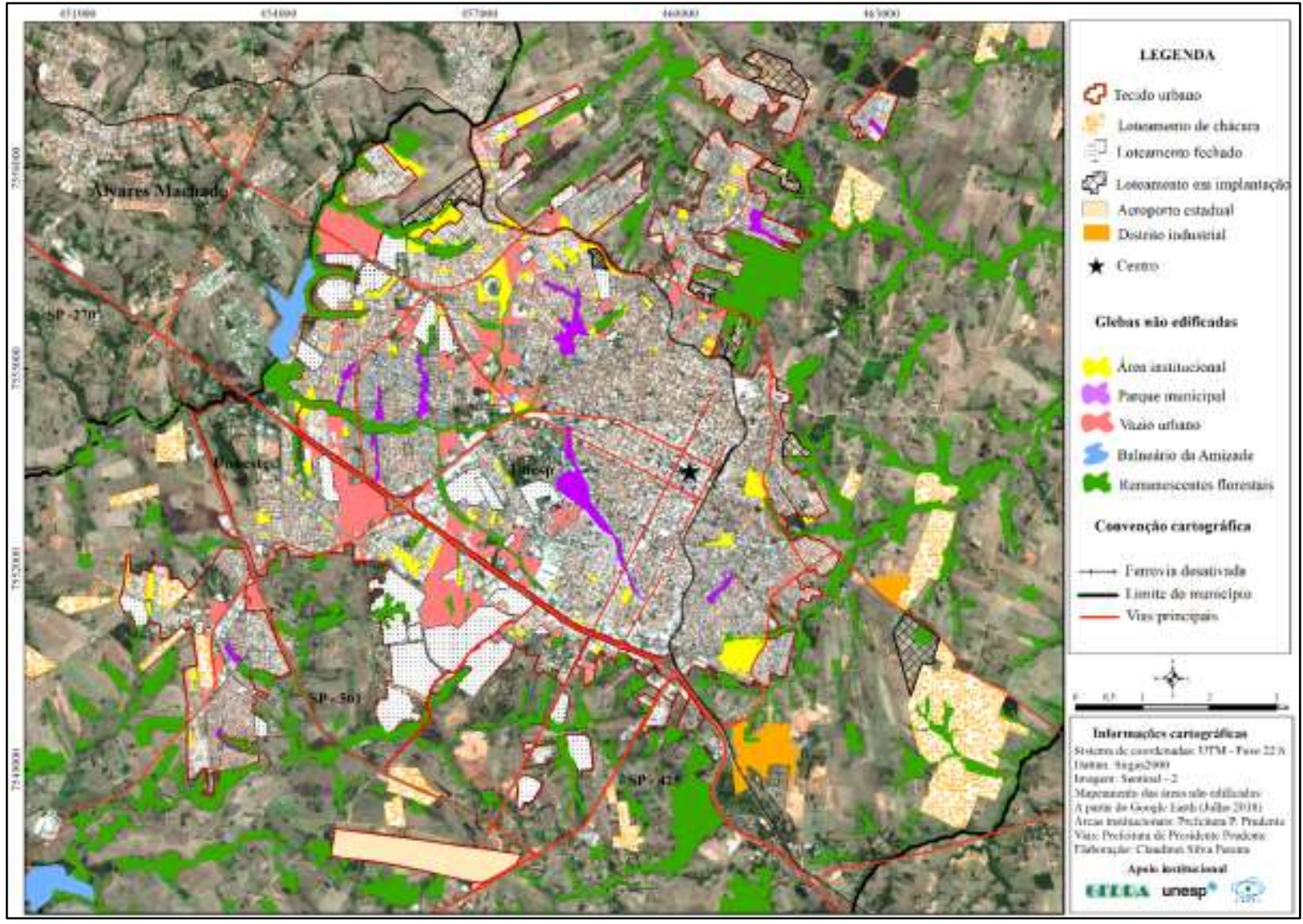

Fonte - Elaborado pelo autor (2020).

No que concerne aos lotes não edificados em 2018, houve redução significativa nos loteamentos anteriores a 2010. Naqueles implantados a partir desse ano, destacam-se os lotes não edificados nas bordas do tecido urbano (Figura 6).

Nos loteamentos abertos mais recentes, discriminamos como em implantação, pois alguns estavam em fase de terraplanagem, outros encontravam-se aptos à edificação, porém não havia transcorrido um tempo razoável para que pudéssemos demarcar os lotes sem edificação, que no caso eram a maioria ou quase todos. Mapeamos 6.069 lotes e outros 3.810 estão nos loteamentos em implantação,

\begin{tabular}{|c|c|c|}
\hline Caminhos de Geografia & Uberlândia-MG & v. 22, n. 83 \\
\hline
\end{tabular}


totalizando 9.879 lotes. Exclui-se os lotes não edificados existentes nos loteamentos fechados e de chácaras.

Depreende-se que os novos loteamentos abertos não surgem da demanda de novos lotes para edificação, mas estão muito mais vinculados à produção da cidade na perspectiva enquanto mercadoria, em que seus espaços são comprados, especulados e vendidos. Consequência desse processo de mercantilização é a permanência dos lotes sem edificação na malha urbana por várias décadas. Também devem ser acrescidos os loteamentos residenciais fechados nos quais o agente incorporador lança uma nova forma de habitat para atrair uma parcela dos potenciais compradores de frações da cidade.

Sposito (1990) tratou da lógica de implantação dos loteamentos e constatou que não havia correlação entre expansão da malha urbana e crescimento populacional na cidade de Presidente Prudente. Em consequência, houve redução na densidade demográfica, pois a cidade crescia mais do que a sua população. Esse recurso foi aplicado por Maia (2019) e reforçou o postulado.

A ampliação territorial urbana relaciona-se ao que Santos (2006, p.114) indica como o processo de mudança da cidade da condição de espaço dos negócios, para se tornar objeto da valorização capitalista: "no setor imobiliário a rentabilidade é garantida sempre a partir do movimento de valorização ou subida de preços dos terrenos". Assim, a apropriação de lotes urbanos corresponde a uma forma de acumulação de riqueza.

Figura 6 - Presidente Prudente: lotes não edificados (2018).

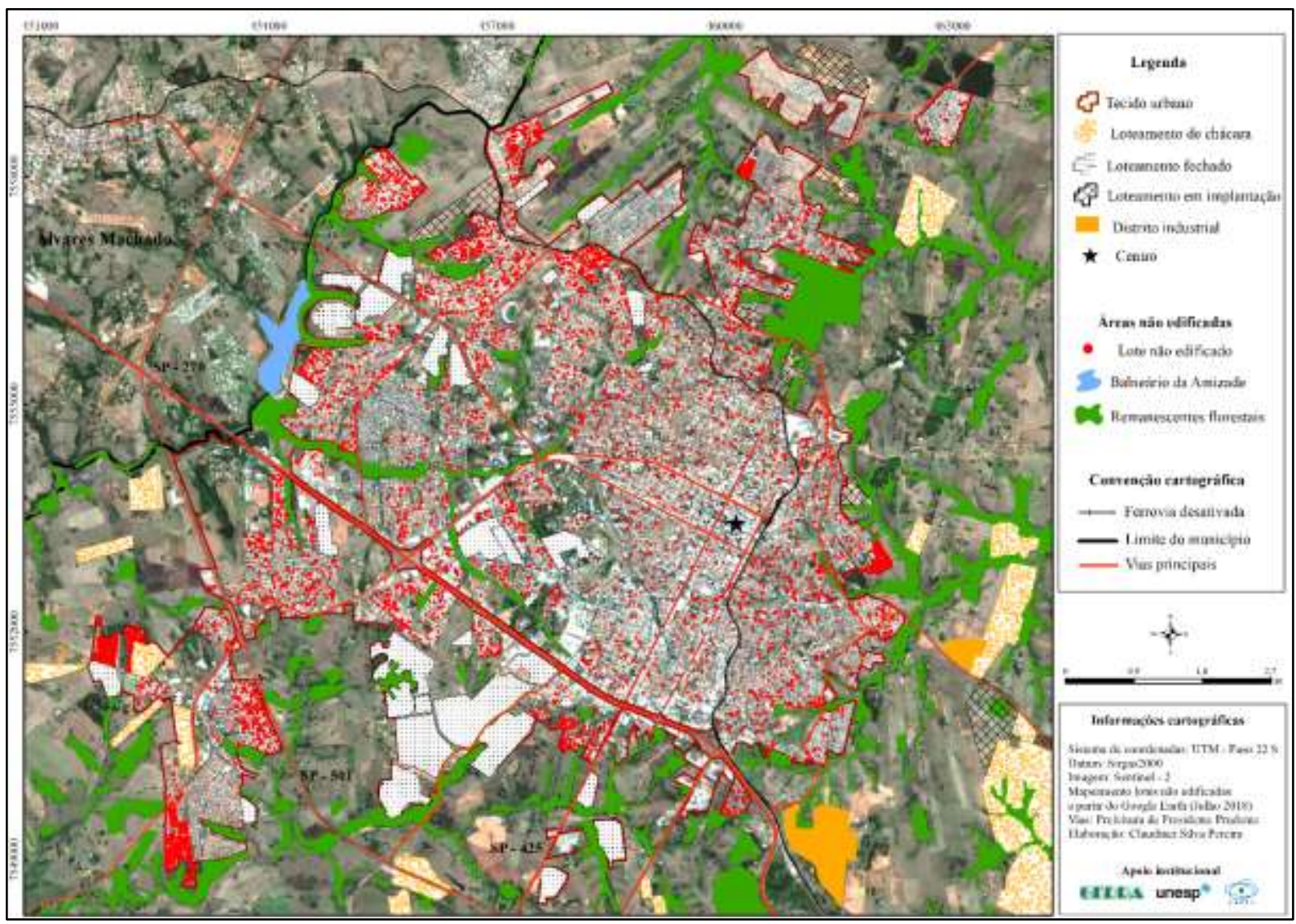

Fonte - Elaborado pelo autor (2020).

Para a mercadoria terra urbana, os mecanismos de produção dos loteamentos não respondem a lógicas estritamente vinculadas aos preceitos de oferta e procura, porque os incorporadores lançam

$\begin{array}{llllll}\text { Caminhos de Geografia } & \text { Uberlândia-MG } & \text { v. 22, n. } 83 & \text { out./2021 } & \text { p. 200-218 } & \text { Página } 215\end{array}$


produtos fundiários/imobiliários e, posteriormente, criam demandas para esses lotes ao agregarem novos atributos: qualidade de vida, espaços verdes, exclusividade, localização privilegiada na cidade, como ressaltado por Smolka (1987) e Sposito e Góes (2013).

A terra urbana deixa de ser apenas um meio ou suporte para produção da cidade (nas condições de moradia, comércio e interações sociais) e transmuta para a produção do espaço urbano como mercadoria ao articular diferentes agentes no processo de reprodução ampliada dos seus capitais. A terra tem centralidade para o entendimento dos processos e lógicas de expansão do tecido urbano na contemporaneidade, e analisados a partir de componentes da morfologia, tais como os vazios urbanos e lotes não edificados, permitem elucidar aspectos relativos à terra como reserva patrimonial ou ativo, nas proposições de Sayad (1977) e Abramo (1989).

\section{CONSIDERAÇÕES FINAIS}

O artigo demonstrou como a cidade na contemporaneidade, com análise empírica para Presidente Prudente, pode ser entendida como produto e mercadoria, pois a terra é comprada e especulada por um conjunto de agentes econômicos e por outras centenas de indivíduos que adquirem frações da cidade, ou seja, os lotes, deixando-os sem edificar por várias décadas. A permanência dos vazios urbanos vinculam-se a fins especulativos, no qual parte destas terras são de propriedade de incorporadoras, que anteciparam a aquisição, formando bancos de terras, e aguardam o momento adequado para lançar novos empreendimentos fundiários/imobiliários.

A articulação de diferentes tipologias dos loteamentos residenciais e áreas não edificadas/parceladas (lotes não edificados, vazios urbanos, terras juridicamente rurais) possibilitam apreender processos vinculados à renda da terra e ao espraiamento do tecido urbano em Presidente Prudente.

A atuação do poder público local ao ampliar o perímetro urbano e implantar às infraestruturas de transporte e serviços básicos, potencializa os interesses privados sobre as terras rurais e urbanas. A regulamentação permissiva no que concerne à expansão descontínua do tecido urbano e ilegalidade no parcelamento dos loteamentos de chácaras beneficia os proprietários fundiários, que assim extraem maiores rendas da terra ao converter o uso do solo de rural para urbano.

A metodologia de mapeamento dos vazios urbanos, áreas institucionais e lotes não edificados mostrouse adequada aos objetivos propostos e é possível de ser utilizada em outros estudos sobre expansão urbana e análise de elementos da morfologia.

O uso de dados do Sistema Nacional de Cadastro Rural tem potencial de desvendar mais elementos pertinentes à propriedade privada da terra pelo capital incorporador e nortear pesquisas relativas aos agentes capitalistas, que ao controlarem glebas, atuam na expansão territorial das cidades. Além disso, como a apropriação de terras em determinadas áreas por grupos econômicos se correlaciona e influencia, via mecanismos políticos, o poder público local na modificação do perímetro urbano para beneficiar os detentores de terras.

\section{AGRACEDIMENTOS}

À Coordenação Aperfeiçoamento de Pessoal de Nível Superior (CAPES) pela concessão da bolsa de doutorado para a realização da pesquisa.

\section{REFERÊNCIAS}

ABRAMO, Pedro. A dinâmica imobiliária: elementos para o entendimento da espacialidade urbana.

Cadernos IPPUR/UFRJ. Ano III - Número especial - Dez. p. 47-70, 1989.

ABREU, Dióres Santos. Formação histórica de uma cidade pioneira paulista: Presidente

Prudente. Faculdade de Filosofia, Ciências e Letras de Presidente Prudente, 1972.

$\begin{array}{llllll}\text { Caminhos de Geografia } & \text { Uberlândia-MG } & \text { v. 22, n. 83 } & \text { out./2021 } & \text { p. 200-218 } & \text { Página } 216\end{array}$


BARCELLA, Bruno Leonardo Silva; MELAZZO, Everaldo Santos. Expansão urbana e dinâmica imobiliária: comparando as estratégias fundiárias dos agentes imobiliários em cidades médias.

Sociedade e Natureza, Uberlândia, v.32, p. 108-125, 2020. https://doi.org/10.14393/SN-v32-2020$\underline{42908}$

BRASIL. Lei № 6.766, de 19 de dezembro de 1979. Dispõe sobre o uso do solo e dá outras providências. Disponível em: http://www.planalto.gov.br/. Acesso em: 15 de julho de 2020.

BRASIL. Lei № 4.504, de 30 de novembro de 1964. Dispõe sobre o Estatuto da Terra e dá outras providências. Disponível em: http://www.planalto.gov.br/ccivil_03/leis. Acesso em: 18 de julho de 2020.

DANIEL, Celso. O poder local no Brasil urbano. Espaço \& Debate, n. 24, p. 26-39, 1988.

HARVEY, David. Os limites do capital. Tradução de Magda Lopes. - 1 ed. - São Paulo: Boitempo, 2013.

HORACIO, Capel. La morfología de las ciudades: sociedad, cultura y paisaje urbano. Barcelona: Ediciones del Sebral, 2013.

INCRA - Instituto Nacional de Colonização e Reforma Agrária. Sistema Nacional de Cadastro de Imóveis Rurais (SNCR). Disponível em: http://www.incra.gov.br/ccir-ccir.

JARAMILLO, Samuel. Hacia una Teoría de la Renta del Suelo. 2. ed. - Bogotá: Universidad de los Andes, Faculdad de Economía, CEDE, Ediciones Uniandes, 2009.

MAIA, Amanda Carvalho. Descontinuidade territorial e formação de vazios urbanos: um padrão de crescimento em cidades médias paulistas. Dissertação (Mestrado em Arquitetura) Universidade Estadual de Campinas, Faculdade de Engenharia Civil, Arquitetura e Urbanismo, 2019.

MARX, Karl. O Capital. Crítica da Economia Política. Livro III - o processo global da produção capitalista. Tradução Rubens Enderle. - São Paulo: Boitempo, 2016.

MELAZZO, Everaldo Santos. Estratégias fundiárias e dinâmicas imobiliárias do capital financeirizado no Brasil. Mercator, Fortaleza, v. 12, número especial (2), p. 29-40, set. 2013.

https://doi.org/10.4215/RM2013.1202.0002

MIYAZAKI, Vitor Koiti. Um estudo sobre o processo de aglomeração urbana: Álvares Machado, Presidente Prudente e Regente Feijó. Dissertação (Mestrado em Geografia). Universidade Estadual Paulista, Faculdade de Ciências e Tecnologia, Presidente Prudente, 2008.

MUMFORD, Lewis. A cidade na história: suas origens, transformações e perspectivas. Tradução Neil R. da Silva. 5 ed. - São Paulo: Martins Fontes, 2008.

NASCIMENTO, Agnaldo da Silva. No vazio, caberiam casas, parques, fábricas... caberia muita cidade. Dissertação (Mestrado em Geografia) - Universidade Estadual Paulista, Faculdade de Ciências e Tecnologia, Presidente Prudente, 2014.

OLIVEIRA, Viviane Fernanda de. Os sentidos da casa própria: condomínios horizontais populares fechados e novas práticas espaciais em Presidente Prudente e São Carlos. São Paulo: Cultura Acadêmica, 2015. https://doi.org/10.7476/9788579837098

POLANYI, Karl. A grande transformação: as origens de nossa época. Tradução Fanny Wrobel. 2 ed.- Rio de Janeiro: Campus, 2000.

PRESIDENTE PRUDENTE. Lei Complementar № 231/2018. Dispõe sobre a Lei de Zoneamento do Uso e Ocupação do Solo do município. Disponível em: http://www.presidenteprudente.sp.gov.br

SANTOS, César Ricardo Simoni. Dos negócios na cidade à cidade como negócio: uma nova sorte de acumulação primitiva do espaço. Revista Cidades, v. 3, n. 5, p. 101-112, 2006. 
SANTOS, Felipe C. A. Silgueiro. O espaço-tempo das políticas habitacionais em Presidente Prudente/SP. Dissertação (Mestrado em Geografia) - Universidade Estadual Paulista, Faculdade de Ciências e Tecnologia, Presidente Prudente, 2020.

SAYAD, João. Preço da terra e mercados financeiros. Revista Pesquisa e Planejamento econômico. Rio de Janeiro. N. 7, v. 3, Dez. p. 623-662, 1977.

SINGER, Paul. O uso do solo urbano na economia capitalista. In: MARICATO, Ermínia (Org.). A produção capitalista da casa (e a cidade) no Brasil industrial. São Paulo: Alfa-Omega, p.21-36, 1978.

SMOLKA, Martin Oscar. O capital incorporador e seus movimentos de valorização. In: Cadernos IPPUR/UFRJ, ano 2, n.1, jan/abr, p. 41-78, 1987.

SPOSITO, Eliseu Savério. Produção e apropriação da renda fundiária urbana em Presidente

Prudente. Tese (Doutorado em Geografia) Faculdade de Letras e Ciências Humanas da Universidade de São Paulo, São Paulo, 1990.

SPOSITO, Maria Encarnação. O chão arranha o céu: a lógica da (re)produção monopolista da cidade. Tese (Doutorado em Geografia) Faculdade de Filosofia, Letras e Ciências Humanas, Universidade de São Paulo, 1991.

SPOSITO, Maria Encarnação. $O$ chão em pedaços: urbanização, economia e cidades no Estado de São Paulo. Tese (Livre-docência e Geografia). Universidade Estadual Paulista Faculdade de Ciências e Tecnologia, Presidente Prudente, 2005.

SPOSITO, Maria Encarnação, GÓES, Eda Maria. Espaços fechados e cidades: insegurança urbana e fragmentação socioespacial. São Paulo, Editora Unesp, 2013.

Recebido em: 26/07/2020

Aceito para publicação em: 28/09/2020 